\title{
Are the conservation areas sufficient to conserve endangered plant species in Korea?
}

\author{
Hyesoon Kang ${ }^{1, *}$, Sookyung Shin ${ }^{1}$ and Hyejin Whang ${ }^{2,3}$ \\ ${ }^{1}$ School of Biological Science and Chemistry, and Basic Science Research Institute, Sungshin Women's University, \\ Seoul 136-742, Korea \\ ${ }^{2}$ Department of Geography, Sungshin Women's University, Seoul 136-742, Korea \\ ${ }^{3}$ Present address: Department of Renewable Resources, University of Alberta, Alberta T6G2H1, Canada
}

\begin{abstract}
Understanding the factors relevant to endangerment and the patterns of habitat locations in relation to protected areas is critically important for the conservation of rare species. Although 64 plant species have recently been listed as endangered species in Korea, this information has, until now, not been available, making appropriate management and conservation strategies impossible to devise. Thus, we collected information on potentially threatening factors, as well as information on the locations in which these species were observed. The potentially threatening factors were classified into seven categories. National parks, provincial parks, ecosystem conservation areas, and wetland conservation areas were defined as protected conservation areas. Korean digital elevation model data, along with the maps of all protected areas were combined with the maps of endangered plant species, and analyzed via Geographic Information Systems (GIS). Excluding the category of "small population", endangered plant species in Korea were associated more frequently with extrinsic factors than intrinsic factors. Considering land surface only, all conservation areas in Korea totaled $4.9 \%$ of the land, far lower than International Union for Conservation of Nature and Natural Resources (IUCN)'s $10 \%$ coverage target. At the species level, $69 \%$ of the endangered plant species were detected in conservation areas, mostly in national parks. However, this result demonstrates that $31 \%$ of endangered species inhabit areas outside the conservation zones. Furthermore, at the habitat level, a large proportion of endangered species were found to reside in unprotected areas, revealing "gaps" in protected land. In the face of rapid environmental changes such as population increases, urbanization, and climate changes, converting these gap areas to endangered species' habitats, or at least including them in habitat networks, will help to perpetuate the existence of endangered species.
\end{abstract}

Key words: endangered plant species, gap, GIS, protected areas, threatening factor

\section{INTRODUCTION}

Extrinsic factors such as habitat loss and degradation, exploitation, invasive species, disease, pollution, and intrinsic factors associated with reproduction and growth rates are generally implicated as the causal factors in the current decrease in biodiversity. According to the International Union for Conservation of Nature and Natural
Resources (IUCN) (2010b), habitat loss and degradation are the most important factors influencing mammals, birds, amphibians, and gymnosperms; however, the importance of other factors varies profoundly depending on the taxa examined. The IUCN (2010a) has recently reported that although diseases and pollution greatly in-

Received 10 October 2010, Accepted 13 October 2010

"Corresponding Author

E-mail: hkang@sungshin.ac.kr

Tel: +82-2-920-7475 
fluence amphibians, and invasive species are a profound influence in the bird population, these same factors exert only a minimal influence on the diversity of gymnosperms. Therefore, without proper knowledge of the factors influencing each species and the extent of such influences, conservation efforts will be difficult to devise and implement successfully. For example, if the species is naturally rare (e.g., geographically limited distribution, small populations, and small habitat requirements), it requires twice the habitat size of a species that is rare as the result of human activities (e.g., forest disturbance, traditional cultivation, and collection activities) (Vellak et al. 2009). The factors mentioned above illustrate that the principal causal factors leading rare species to the brink of extinction are largely associated with the ecology of species. However, thus far, ecological concepts have not been applied to the process of listing and managing rare or endangered species in Korea.

Since habitat loss and degradation are the primary factors responsible for the extinction of species of diverse taxa, the IUCN (1993) has established the objective of conserving $10 \%$ of land in each country. Rapid industrialization and urbanization, post-1970s, has caused some real problems, such as the fragmentation of ecosystems, destruction of landscapes, and pollution. For example, the proportion of forests--the main habitat of many endangered species--has been declining $0.16 \%$ every year since the 1970s (Chang and Seok 1997). The national parks of Korea account for $80 \%$ of all conservation areas and represent relatively well-preserved natural systems. However, the mountain range that runs through most of the length of the Korean Peninsula, in which most of the national parks are located, is interrupted every 8.3 $\mathrm{km}$, by a total of 82 roads (61 paved roads and 21 nonpaved roads) (Green Korea United 2008). Thus, even the national parks are not truly safe from habitat loss and degradation. This, in combination with the fact that climate changes require dynamic conservation strategies (Mawdsley et al. 2009), illustrates the urgent need to evaluate the locations and sizes of conservation areas in relation to the distributions of endangered species.

IUCN's guidelines for using the IUCN Red List categories and criteria (ver. 3.1) divide the extant species into 6 groups depending on the degree of their endangerment (i.e., reduction of their population size, current population size, geographic range, and extinction probabilities). On the other hand, endangered species and species in need of special care have been adjusted to class I and II, respectively, by an amendment to the Korean Wildlife Protection Act (Ministry of Environment 2006). Class I endangered wild animals and class I plants are species whose populations have been drastically reduced, thus leading to their endangerment, and class II includes species that are under threat of endangerment if the threatening factors are not removed or relieved. However, several authors (Kim 1994, Bang and Ahn 2005, Chang et al. 2005) claim that the Ministry of Environment's definitions are quite ambiguous. The lack of clarity in these definitions means that even if a species is designated as endangered, specific management and conservation strategies, as well as showing proof of release from endangerment, will be problematic. Another problem we are currently experiencing is that most endangered species have been defined as endangered on the basis of their ornamental or economic value, rather than on the basis of Korean biodiversity. Furthermore, there has been no confirmation on the proportion of current conservation areas that function as habitats for the endangered species, despite the fact that habitat conservation is a key factor in the maintenance of biodiversity.

A number of activities targeted toward the conservation and restoration of endangered animals and plants will be attempted, with a focus on existing national parks (Ministry of Environment 2008). However, in order to maintain the evolutionary potential of endangered species, if possible, conservation efforts must be conducted in situ rather than ex situ (Primack 1993, Possingham et al. 2005). Thus, in this research, we have attempted to explore the overlapping pattern of the endangered species' habitats to the areas in which they seek refuge. By focusing on the overlap of endangered species' habitats and conservation areas, we can locate the gap areas necessary for the conservation of endangered species. In particular, we wish to answer the following questions: 1) What are the factors that have threatened the 64 endangered plant species in Korea?; 2) What is the geographic distribution of those plants?; and 3) Regarding habitats, what sorts of conservation plans can we offer to preserve these plants?

\section{MATERIALS AND METHODS}

\section{Factors causing species endangerment}

The Wildlife Protection Act of Korea, which was first enforced in 2005, designated a total of 64 plant species (8 and 56 species in classes I and II, respectively) as endangered species (Table 1). We collected information from various papers (e.g., Hyun 2002, Chang et al. 2005), the internet, and news articles, on threatened or endangered 
Table 1. List of endangered plant species designated by the Wildlife Protection Act in Korea

\begin{tabular}{|c|c|c|}
\hline Endangerment class & Family & Species \\
\hline \multirow[t]{4}{*}{ I } & Diapensiaceae & Diapensia lapponica var. obovata \\
\hline & Leguminosae & Euchresta japonica \\
\hline & Orchidaceae & $\begin{array}{l}\text { Aerides jopnicum, Cymbidium kanran, C. lancifolium, } \\
\text { Cypripedium japonicum, Neofinetia falcata }\end{array}$ \\
\hline & Rosaceae & Cotoneaster wilsonii \\
\hline \multirow[t]{32}{*}{ II } & Amaryllidaceae & Lycoris chinensis var. sinuolata \\
\hline & Apiaceae & Bupleurum latissimum, Cicuta virosa \\
\hline & Araliaceae & Acanthopanax senticosus \\
\hline & Aspleniaceae & Asplenium antiquum \\
\hline & Asteraceae & Aster altaicus var. uchiyamae, Leontopodium coreanum \\
\hline & Berberidaceae & Leontice microrrhyncha, Jeffersonia dubia \\
\hline & Chloranthaceae & Sarcandra glabra \\
\hline & Crassulaceae & Hylotelephium ussuriense \\
\hline & Droseraceae & Drosera peltata var. nipponica \\
\hline & Ericaceae & Arctous ruber, Rhododendron aureum \\
\hline & Fabaceae & $\begin{array}{l}\text { Astragalus membranaceus, Echinosophora koreensis, } \\
\text { Milletia japonica }\end{array}$ \\
\hline & Fagaceae & Quercus gilva \\
\hline & Gentianaceae & Menyanthes trifoliata \\
\hline & Hamamelidaceae & Corylopsis gotoana var. coreana \\
\hline & Iridaceae & Iris dichotoma, I. koreana, I. odaesanensis \\
\hline & Isoetaceae & Isoetes japonica \\
\hline & Lentibulariaceae & Utricularia yakusimensis \\
\hline & Liliaceae & $\begin{array}{l}\text { Lilium cernuum, Polygonatum stenophyllum, Smilacina bicolor, } \\
\text { Trillium tschonoskii }\end{array}$ \\
\hline & Malvaceae & Hibiscus hamabo \\
\hline & Nymphaeaceae & Brasenia schreberi, Euryale ferox \\
\hline & Oleaceae & Abeliophyllum distichum, Osmanthus insularis \\
\hline & Ophioglossaceae & Mankyua chejuense \\
\hline & Orchidaceae & $\begin{array}{l}\text { Cymbidium macrorrhizum, Cypripedium guttatum var. koreanum, } \\
\text { Galeola septentrionalis, Sarcanthus scolopendrifolius, } \\
\text { Vexillabium yakushimense var. nakaianum }\end{array}$ \\
\hline & Primulaceae & Trientalis europaea var. arctica \\
\hline & Psilotaceae & Psilotum nudum \\
\hline & Ranunculaceae & $\begin{array}{l}\text { Aconitum austrokoreense, A. koreanum, Paeonia obovata, } \\
\text { Ranunculus kazusensis, Thalictrum coreanum }\end{array}$ \\
\hline & Rhamnaceae & Berchemia berchemiaefolia, Paliurus ramosissimus \\
\hline & Rubiaceae & Lasianthus japonicus \\
\hline & Saururaceae & Saururus chinensis \\
\hline & Saxifragaceae & Kirengeshoma koreana, Rodgersia tabularis \\
\hline & Scrophulariaceae & Scrophularia takesimensis \\
\hline & Violaceae & Viola raddeana, $V$. websteri \\
\hline
\end{tabular}

Endangered species are classified into two groups--classes I and II--according to presumed endangerment risk (see text) 
species, and the potentially dangerous factors threatening endangered species. In an attempt to identify the extent to which endangered species are endemic, we also acquired information regarding the endemism of endangered species from the Ministry of Environment (2005a). We categorized these factors via a slight modification of Groom's method (2005) (Table 2). First, we divided the factors into intrinsic and extrinsic factors (Table 2). The intrinsic factors include 1) limited habitats, 2) unique ecological characteristics, and 3) small population sizes. Small population may be the cause or result of endangerment; however, as there was no historical evidence for a reduction in population size, we determined that population size is an intrinsic factor that result in species endangerment. Small population size was applied to all 64 endangered plant species. Extrinsic factors are attributable to human activities and natural catastrophes, and include 1) habitat loss and degradation, 2) commercial or personal exploitation, 3) climate change, and 4) unintentional exploitation. It is more common for species to become endangered as the result of several factors, as opposed to a single factor. For example, in the case of Cypripedium japonicum, habitat loss, human use, and unique ecological characteristics are all factors that have led to their endangerment. Therefore, the total number of factors that cause endangerment is far greater than the total number of species investigated.

\section{Habitats of endangered plant species in Korea}

We used 1:40,000 scale digital maps of Korea to evaluate the correlation between the distributions of endangered plant species and protected conservation areas (national parks, provincial parks, ecosystem conservation areas, and wetland conservation areas), and to confirm gap areas. Based on the biotic resources distribution map (Ministry of Environment 2005c), we digitized the habitats occupied by endangered plant species. Habitat information obtained after 2003 was expressed as points. When the habitat information obtained from various sources was not sufficiently precise, we noted the information as points on the administrating agencies governing the area, such as the town hall.

National parks, provincial parks, ecosystem conservation areas, and wetland conservation areas were defined as protected conservation areas. Information regarding the location and size of these areas was collected (Ministry of Environment 2003, 2007, National Parks of Korea 2009). Korean digital elevation map (DEM) data, maps of national rivers and class I regional rivers (National Geo-

Table 2. Categories of potentially threatening factors responsible for endangered plant species in Korea

\begin{tabular}{|c|c|c|}
\hline Factors responsible for endangerment & Description & Examples \\
\hline \multicolumn{3}{|l|}{ Intrinsic factor } \\
\hline Limited habitat & $\begin{array}{l}\text { Endemic species; species inhabiting only } \\
\text { islands or wetlands; species occurring only } \\
\text { at sites above certain elevation }\end{array}$ & $\begin{array}{l}\text { Abeliophyllum distichum, Aster altaicus var. } \\
\text { uchiyamae, Corylopsis gotoana var. coreana, } \\
\text { Diapensia lapponica var. obovata" }\end{array}$ \\
\hline Unique ecological characteristic & $\begin{array}{l}\text { Species being mutualistic with certain } \\
\text { fungi; species that grow slowly and } \\
\text { reproduce at low rates }\end{array}$ & $\begin{array}{l}\text { Aerides japonicum", Galeola septentrionalis, } \\
\text { Kirengeshoma koreana, Sarcanthus } \\
\text { scolopendrifolius }\end{array}$ \\
\hline Small population & $\begin{array}{l}\text { Species typically consisting of small } \\
\text { populations }\end{array}$ & All endangered species \\
\hline \multicolumn{3}{|l|}{ Extrinsic factor } \\
\hline Habitat loss and degradation & $\begin{array}{l}\text { Species of which habitats have been lost or } \\
\text { modified through various human activities }\end{array}$ & $\begin{array}{l}\text { Bupleurum latissimum, Mankyua chejuense, } \\
\text { Ranunculus kazusensis, Trientalis europaea } \\
\text { var. arctica }\end{array}$ \\
\hline Commercial or personal exploitation & $\begin{array}{l}\text { Species that have been exploited for } \\
\text { personal possession or commercial } \\
\text { purpose }\end{array}$ & $\begin{array}{l}\text { Acanthopanax senticosus, Asplenium } \\
\text { antiquum, Cypripedium japonicum, } \\
\text { Neofinetia falcata }\end{array}$ \\
\hline Climate change & $\begin{array}{l}\text { Alpine species that are sensitive to climate } \\
\text { change }\end{array}$ & $\begin{array}{l}\text { Diapensia lapponica var. obovata, } \\
\text { Leontopodium coreanum }\end{array}$ \\
\hline Unintentional exploitation & $\begin{array}{l}\text { Species that have been exploited as } \\
\text { medicinal herbs by misidentification }\end{array}$ & Milletia japonica, Thalictrum coreanum \\
\hline
\end{tabular}

"Species in endangerment class I. 
graphic Information Institute 2003), along with the maps of all protected conservation areas, were combined with the maps of endangered plant species, and subsequently edited. ArcView3.2 and ArcMap ver 9.0 (Environmental Systems Research Institute 2004) were used for analysis.

We assessed the overall pattern of habitat distribution of endangered plant species by combining all of the maps onto eight map layers. We then narrowed our focus to the Gangwon Province and islands such as Gangwha, Ulleung, and Jeju (Jeju Province), where the endangered species' habitats were concentrated. For Jeju Island, the zoning imposed by the United Nations Educational, Scientific and Cultural Organization (UNESCO)'s Programme on Man and the Biosphere (MAB) was also taken into consideration. We screen-digitized and converted the surface zoning data (core, buffer, and transition areas) into polygon data. Digital maps of Hallasan National Park and other conservation areas were then combined with the maps of endangered species' habitats. We magnified Gangwon Province and Gangwha Island from the overall map and confirmed the locations of the species. Finally, we enlarged the island of Ulleung based on the satellite images provided by Ministry of Environment (2005b) and saved it as a TIFF file. We then combined this with a habitat map of the endangered species, thus generating individual data.

In order to evaluate the relationship between the size of conservation areas and the numbers of endangered species, we conducted a regression analysis for 17 national parks (excluding three seashore and marine national parks, i.e., Taeanhaean, Dadoehaehaesang, and Hallyeohaesang National Parks, out of 20 national parks) located on land. Because the majority of conservation areas are national parks, the remainder of the conservation areas, i.e., provincial parks, ecosystem conservation areas, and wetland conservation areas, were described as secondary conservation areas.

\section{RESULTS}

\section{Threatening factors}

After analyzing the factors that can cause species endangerment, the principal intrinsic factors were determined as "small population" (64 species) and "limited habitat" (40 species). The most common extrinsic factors were "commercial or personal exploitation" (39 species), and "habitat loss and degradation" (26 species) (Fig. 1). Therefore, when treating small population as an intrin-

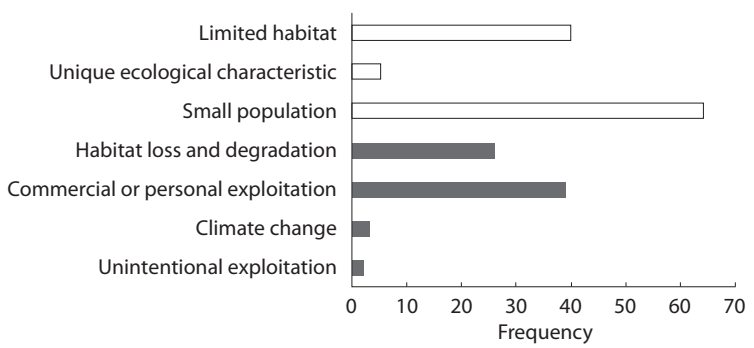

Fig. 1. Frequencies of factors assumed to have adversely affected 64 endangered species in Korea. Since more than one factor is assumed to have affected the species, the total sum of frequencies is greater than 64 . White bars represent intrinsic factors, while grey bars represent extrinsic factors.

sic factor, intrinsic factors were determined to affect the species more profoundly than extrinsic factors $(39 \%$ vs. $61 \%)$. Excluding small population, limited habitat and commercial or personal exploitation were the most threatening factors, followed by habitat loss and degradation. Thus, excluding small population, we found that 1.5 times more species were influenced by extrinsic factors than by intrinsic factors.

\section{Size of protected conservation areas}

Among all conservation areas $\left(4,850.498 \mathrm{~km}^{2}\right)$ in Korea, the size of national parks (excluding three seashore and marine national parks) totaled $3,898.948 \mathrm{~km}^{2}$, which is $80 \%$ of all the conservation areas, and $3.9 \%$ of the country's land (Fig. 2). The rest of the conservation areas included 21 provincial parks $\left(769.5 \mathrm{~km}^{2}\right), 12$ ecosystem conservation areas $\left(102.04 \mathrm{~km}^{2}\right)$, and 7 wetland conservation areas $\left(80.01 \mathrm{~km}^{2}\right)$. The total conservation areas amounted to $4.9 \%$ of the country's land. The mean size of the national parks $\left(\overline{\mathrm{X}}=229.3 \mathrm{~km}^{2}\right)$ was far larger than that of the secondary conservation areas: provincial park $\left(\overline{\mathrm{X}}=36.6 \mathrm{~km}^{2}\right)$, ecosystem conservation area $\left(\overline{\mathrm{X}}=8.5 \mathrm{~km}^{2}\right)$, and wetland conservation area $\left(\overline{\mathrm{X}}=11.4 \mathrm{~km}^{2}\right)$.

\section{Distribution of endangered plant species}

At the species level, 69\% (5 and 39 species in class I and II, respectively) of the endangered plant species were distributed throughout 20 national parks (Figs. 2 and 3). The number of endangered species increased with the size of the national parks (Fig. 4). For example, large national parks such as Jirisan $\left(471.8 \mathrm{~km}^{2}\right)$, Seoraksan $\left(398.5 \mathrm{~km}^{2}\right)$ and Songnisan $\left(274.5 \mathrm{~km}^{2}\right)$ National Parks included more than ten endangered species, whereas smaller parks such as Wolchulsan $\left(56.1 \mathrm{~km}^{2}\right)$ and Gyeryongsan $\left(64.7 \mathrm{~km}^{2}\right)$ National Parks included only a single endangered spe- 


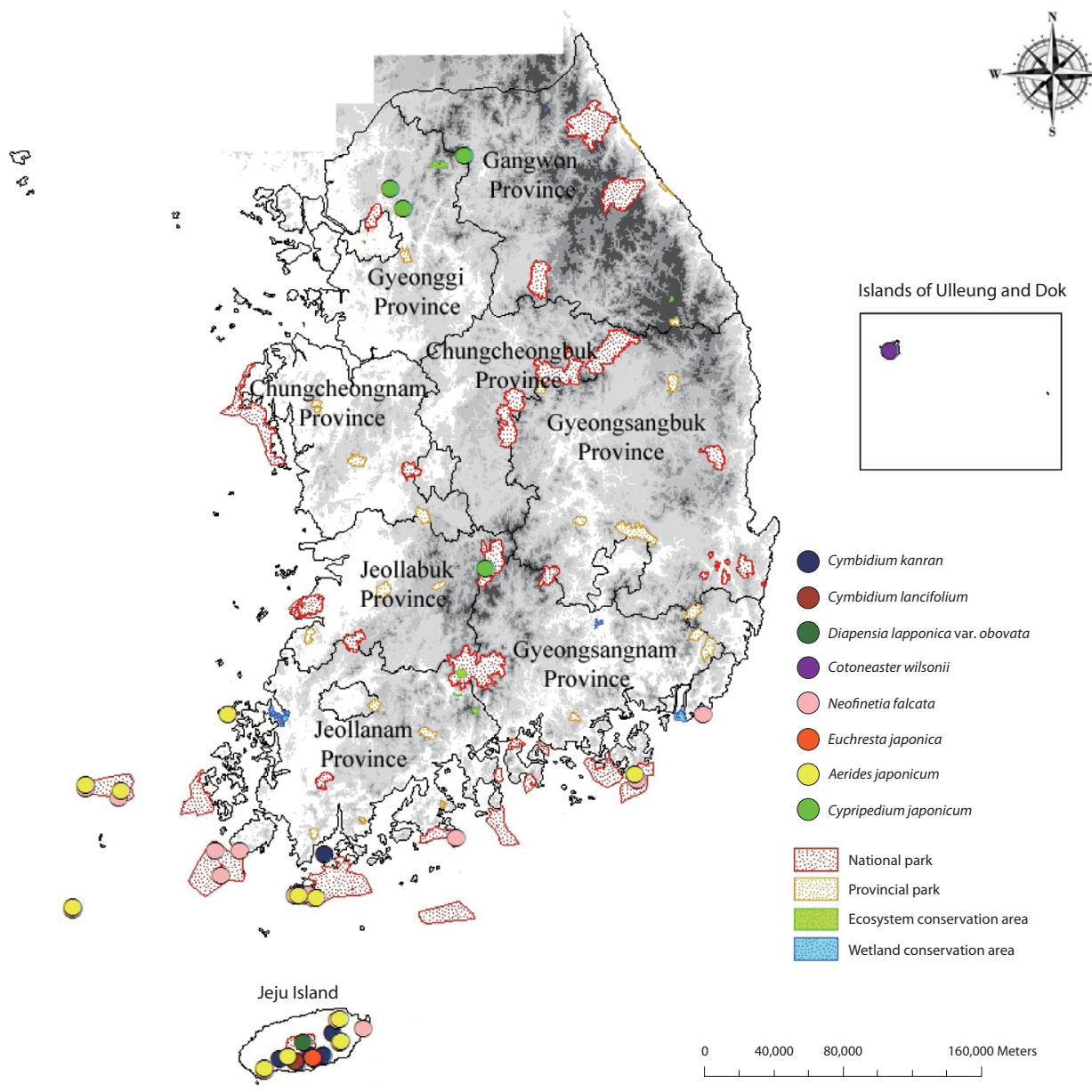

Fig. 2. Map showing the habitats of endangerment class I species $(N=8)$, overlaid with various conservation areas in Korea (20 national parks, 21 provincial parks, 12 ecosystem conservation areas, and 7 wetland conservation areas).

cies each. The national parks differed from one another not only in the number of endangered species but also in the species identities (Table 3). A total of 20 species such as Aster altaicus var. uchiyamae, Euchresta japonica, Lasianthus japonicus, and Polygonatum stenophyllum were not detected in any national parks, and 30 species such as Arctous ruber, Diapensia lapponica var.obovata, Hylotelephium ussuriense, and Viola websteri were distributed only in one or two national parks. By way of contrast, Acanthopanax senticosus, Iris koreana, I. odaesanensis, Lilium cernuum, Paeonia obovata, and Trientalis europaea var. arctica existed in more than five national parks each. In conservation areas other than national parks, there were seven endangered species, although none of these were class I species. Two of those seven species ( $L e-$ ontice microrrhyncha, Menyanthes trifoliata) inhabited only secondary conservation areas, while five (Berchemia berchemiaefolia, Iris odaesanensis, Leontice microrrhyncha, Lycoris chinensis var. sinuolata, and Smilacina bi- color) also appeared in national parks (Table 3).

At the habitat level, class I species usually appeared on the southern coast of the peninsula and Jeju Island, and class II species were distributed more broadly (Figs. 2 and 3). However, depending on the endangered species, profound differences in habitat distribution were observed. Endangered species such as Jeffersonia dubia, Lilium cernuum, and Smilacina bicolor were distributed relatively widely, while most endangered species were distributed in a very limited number of habitats. For example, Asplenium antiquum, Euchresta japonica, Paliurus ramosissimus, and Psilotum nudum were found only on Jeju Island, Echinosophora koreensis and Rhododendron aureum only in the Gangwon Province, and Hylotelephium ussuriense only in Gyeongsangbuk Province. Additionally, Aconitum austrokoreense usually appeared in the Gyeongsangnam Province and Berchemia berchemiaefolia usually appeared in the Gyeongsangbuk Province.

Endangered species distributions were focused largely 

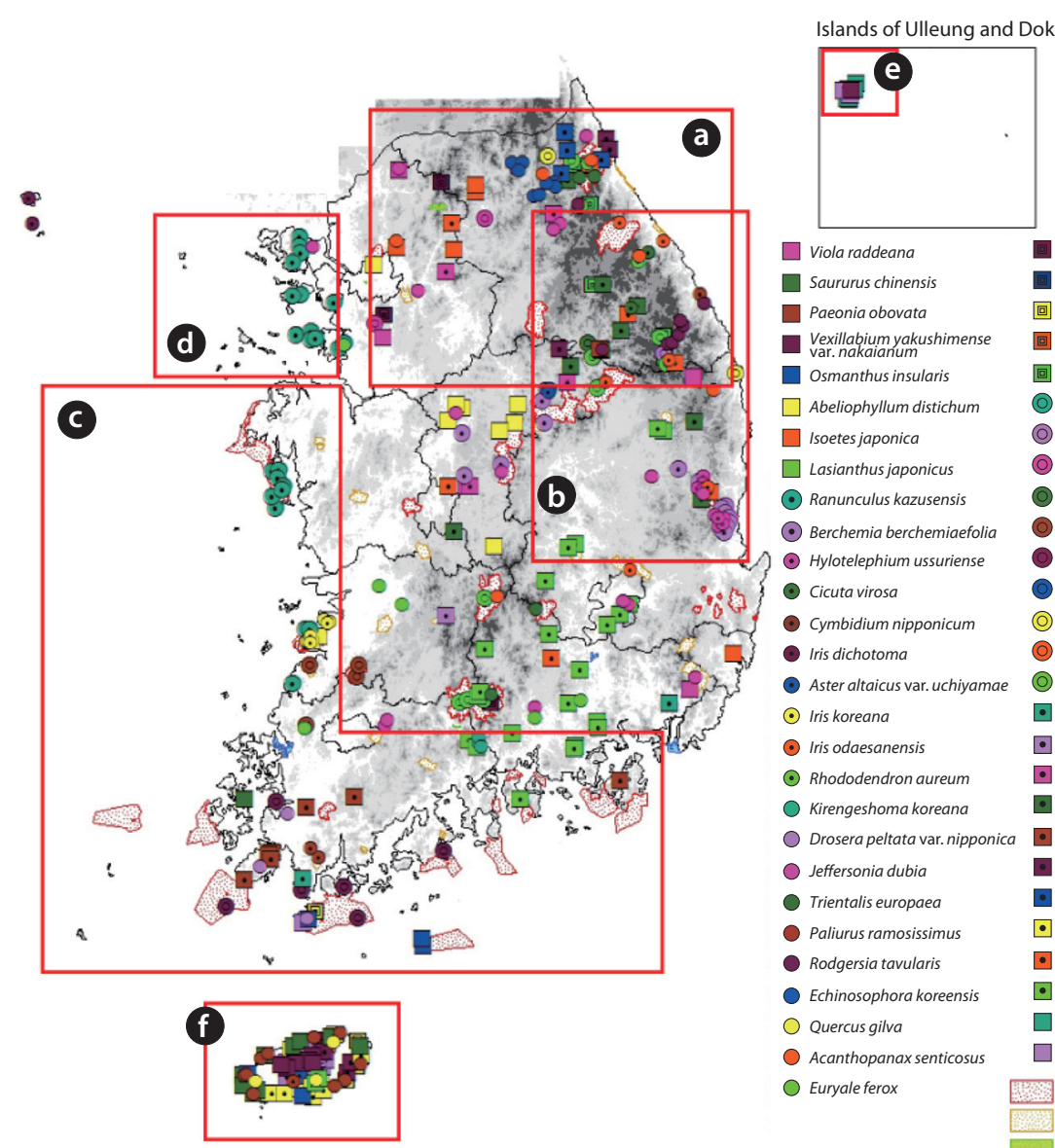

$\begin{array}{ll}\square \text { Viola raddeana } & \text { Corylopsis coreana } \\ \square \text { Saururus chinensis } & \text { Astragalus membranaceus } \\ \square \text { Paeonia obovata } & \text { 回 Hibiscus hamabo } \\ \text { Vexillabium yakushimense } & \text { 圖 Arctous ruber } \\ \text { var.nakaianum } \\ \text { Osmanthus insularis } & \text { 回 Leontice microrrhyncha }\end{array}$

$\square$ Abeliophyllum distichum

$\square$ Isoetes japonica

$\square$ Lasianthus japonicus

- Ranunculus kazusensis

- Berchemia berchemiaefolia

- Hylotelephium ussuriense

- Cicuta virosa

- Cymbidium nipponicum

- Iris dichotoma

- Aster altaicus var. uchiyama

$\odot$ Iris koreana

- Iris odaesanensis

$\odot$ Rhododendron aureum

Kirengeshoma koreana

Drosera peltata var. nipponica

- Jeffersonia dubia

- Trientalis europaea

- Paliurus ramosissimus

- Rodgersia tavularis

- Echinosophora koreensis

Quercus gilva

- Acanthopanax senticosus

Euryale ferox

(C) Asplenium antiquum

() Cypripedium guttatum

() Trillium tschonoskii

() Polygonatum stenophyllum

(1) Lycoris chinensis var. sinuolata

- Sarcanthus scolopendrifolius

- Sarcandra glabra

(0) Menyanthes trifoliata

() Mankyua chejuense

(0) Smilacina bicolor

- Utricularia yakusimensis

- Galeola septentrionalis

- Viola websteri

- Thalictrum coreanum

- Milletiajaponica

- Brasenia schreberi

- Leontopodium coreanum

- Psilotum nudum

- Lilium cernuum

- Aconitum austrokoreense

$\square$ Scrophularia takesimensis

$\square$ Bupleurum latissimum

National park

Provincial park

Ecosystem conservation area

Wetland conservation area

Fig. 3. Map showing the habitats of endangerment class II species $(N=56)$, overlaid with various conservation areas in Korea (20 national parks, 21 provincial parks, 12 ecosystem conservation areas, and 7 wetland conservation areas).

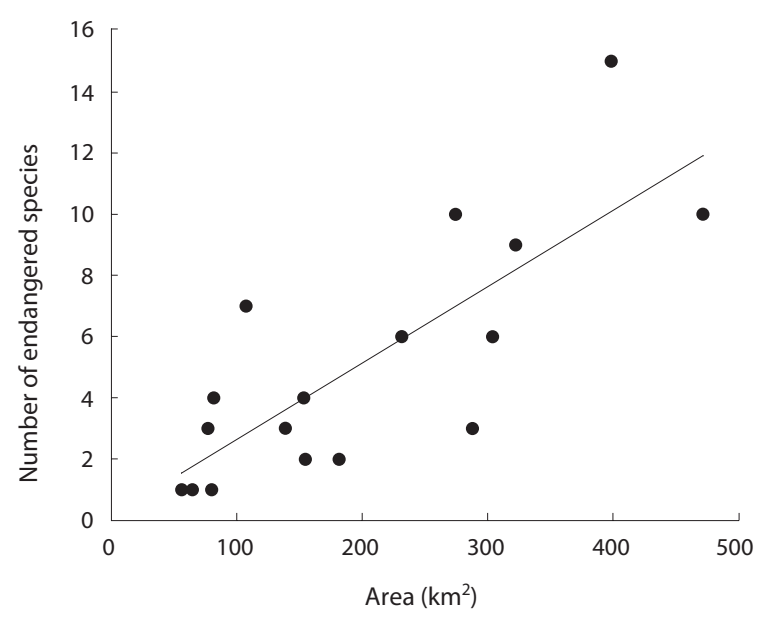

Fig. 4. Relationship between the size of national parks and the number of endangered species occurring in each park in Korea. Only 17 terrestrial national parks were employed in the analysis. Regression lines were drawn to illustrate the positive relationship between the park area and the number of endangered species in each park $(\mathrm{Y}=0.025 \mathrm{X}+0.158, r=$ $0.79, P<0.001, N=17)$. in unprotected areas, particularly in the mountain regions of Gangwon Province and Gyeongsangbuk Province, the southwestern coast, and islands including Gangwha, Jeju, and Ulleung. In the Gangwon Province, Rodgersia tabularis, Echinosophora koreensis, and Acanthopanax senticosus were detected in unprotected areas (Fig. 5a). In the region separating the Odaesan and Juwangsan National Parks, Aconitum austrokoreense, Rodgersia tabularis, Leontice microrrhyncha, and Thalictrum coreanum distributions were found (Fig. 5b). A number of species, including Drosera peltata var. nipponica, Iris dichotoma, Milletia japonica, and Ranunculus kazusensis, inhabit the western and southern coasts where the coastline is very complex and a number of islands $(3,418)$ exist (Fig. 5c). Many endangered species existed outside the shore and marine national parks. In particular, $R a$ nunculus kazusensis was distributed throughout the Taeanhaean National Park, as well as in many areas that were not classed as protected areas, such as the Gangwha and 
Table 3. Endangered plant species identified at each site belonging to different types of conservation areas in Korea

\begin{tabular}{|c|c|c|c|c|c|c|c|}
\hline Types of conservation areas & & & & Site & & & \\
\hline \multirow{20}{*}{ National park } & Gyeryongsan & Wolchulsan & $\begin{array}{l}\text { Byeonsan- } \\
\text { bando }\end{array}$ & Chiaksan & Taeanhaean & Gayasan & Gyeongju \\
\hline & P. obov & I. kore & $\begin{array}{l}\text { A. dist } \\
\text { I. kore }\end{array}$ & $\begin{array}{l}\text { A. sent } \\
\text { I. odae }\end{array}$ & $\begin{array}{l}\text { L. core } \\
\text { R. kazu }\end{array}$ & $\begin{array}{l}\text { L. cern } \\
\text { P. obov } \\
\text { T. euro }\end{array}$ & $\begin{array}{l}\text { I. kore } \\
\text { I. odae } \\
\text { P. obov }\end{array}$ \\
\hline & $\underline{\text { Woraksan }}$ & Naejangsan & Hallasan & $\begin{array}{l}\underline{\text { Hallyeo- }} \\
\text { haesang }\end{array}$ & $\underline{\text { Deogyusan }}$ & Odaesan & Juwangsan \\
\hline & $\begin{array}{l}\text { B. berc } \\
\text { L. cern } \\
\text { V. webs }\end{array}$ & $\begin{array}{l}\text { C. macr } \\
\text { I. kore } \\
\text { L.chin } \\
\text { V.yaku }\end{array}$ & $\begin{array}{l}\text { D. lapp* } \\
\text { G. sept } \\
\text { I. japo } \\
\text { U. yaku }\end{array}$ & $\begin{array}{l}\text { A. japo* } \\
\text { C. goto } \\
\text { C. macr } \\
\text { M. japo } \\
\text { N. falc }\end{array}$ & $\begin{array}{l}\text { A. sent } \\
\text { C. japo" } \\
\text { L. cern } \\
\text { P. obov } \\
\text { R. tabu } \\
\text { S. bico }\end{array}$ & $\begin{array}{l}\text { A. sent } \\
\text { I. odae } \\
\text { P. obov } \\
\text { R. tabu } \\
\text { S. bico } \\
\text { T. euro }\end{array}$ & $\begin{array}{l}\text { A. sent } \\
\text { B. berc } \\
\text { H. ussu } \\
\text { I. odae } \\
\text { J. dubi } \\
\text { L. cern } \\
\text { T. core }\end{array}$ \\
\hline & $\underline{\text { Sobaeksan }}$ & Songnisan & ఏirisan & $\begin{array}{l}\text { Dadoehaehae- } \\
\underline{\text { sang }}\end{array}$ & $\underline{\text { Seoraksan }}$ & & \\
\hline & A. aust & A. dist & A. aust & A. japo* & A. kore & & \\
\hline & A. sent & A. kore & A. kore & A. sent & A. memb & & \\
\hline & E. kore & A. sent & A. memb & C. kanr ${ }^{*}$ & A. rube & & \\
\hline & I. kore & B. berc & A. sent & C. macr & C. gutt & & \\
\hline & I. odae & I. kore & C. goto & D. pelt & I. kore & & \\
\hline & L.cern & I. odae & I. kore & G. sept & J. dubi & & \\
\hline & P. obov & J. dubi & Pobov & H. hama & L.cern & & \\
\hline & S. bico & L.cern & R. tabu & М. јаро & L. core & & \\
\hline & T. euro & P. obov & S. bico & N. falc ${ }^{*}$ & L. micr & & \\
\hline & & T. core & T. euro & O. insu & P. obov & & \\
\hline & & & & Q. gilv & R. aure & & \\
\hline & & & & S. chin & S. bico & & \\
\hline & & & & S. scol & T. core & & \\
\hline & & & & T. euro & T. euro & & \\
\hline & & & & U. yaku & T. tsch & & \\
\hline \multirow[t]{2}{*}{ Provincial park } & Duryunsan & $\begin{array}{l}\text { Mungyeong- } \\
\text { saejae }\end{array}$ & $\underline{\text { Seonunsan }}$ & Taebaeksan & Palgongsan & & \\
\hline & C. macr & B. berc & L. chin & $\begin{array}{l}\text { I. odae } \\
\text { L. micr } \\
\text { S. bico }\end{array}$ & I. odae & & \\
\hline
\end{tabular}

Ecosystem conservation area $\quad \underline{\text { irisan }}$

S. bico

Wetland conservation area Daeamsan

M. trif

A. aust, Aconitum austrokoreense; A. dist, Abeliophyllum distichum; A. japo, Aerides japonicum; A. kore, Aconitum koreanum; A. memb, Astragalus membranaceus; A. rube, Arctous ruber; A. sent, Acanthopanax senticosus; B. berc, Berchemia berchemiaefolia; C. goto, Corylopsis gotoana var. coreana; C. gutt, Cypripedium guttatum var. koreanum; C. japo, Cypripedium japonicum; C. kanr, Cymbidium kanran; C. macr, Cymbidium macrorrhizum; D. lapp, Diapensia lapponica var. obovata; D. pelt, Drosera peltata var. nipponica; E. kore, Echinosophora koreensis; G. sept, Galeola septentrionalis; H. hama, Hibiscus hamabo; H. ussu, Hylotelephium ussuriense; I. japo, Isoetes japonica; I. kore, Iris koreana; I. odae, Iris odaesanensis; J.dubi, Jeffersonia dubia; L. cern, Lilium cernuum; L. chin, Lycoris chinensis var. sinuolata; L. core, Leontopodium coreanum; L. micr, Leontice microrrhyncha; M. japo, Milletia japonica; M. trif, Menyanthes trifoliate; N. falc, Neofinetia falcate; O. insu, Osmanthus insularis; P. obov, Paeonia obovata; Q. gilv, Quercus gilva; R. aure, Rhododendron aureum; R. kazu, Ranunculus kazusensis; R. tabu, Rodgersia tabularis; S. bico, Smilacina bicolor; S. chin, Saururus chinensis; S. scol, Sarcanthus scolopendrifolius; T. core, Thalictrum coreanum; T. euro, Trientalis europaea var. arctica; T. tsch, Trillium tschonoskii; U. yaku, Utricularia yakusimensis; V. webs, Viola websteri; V. yaku, Vexillabium yakushimense var. nakaianum.

*Species in endangerment class I. 

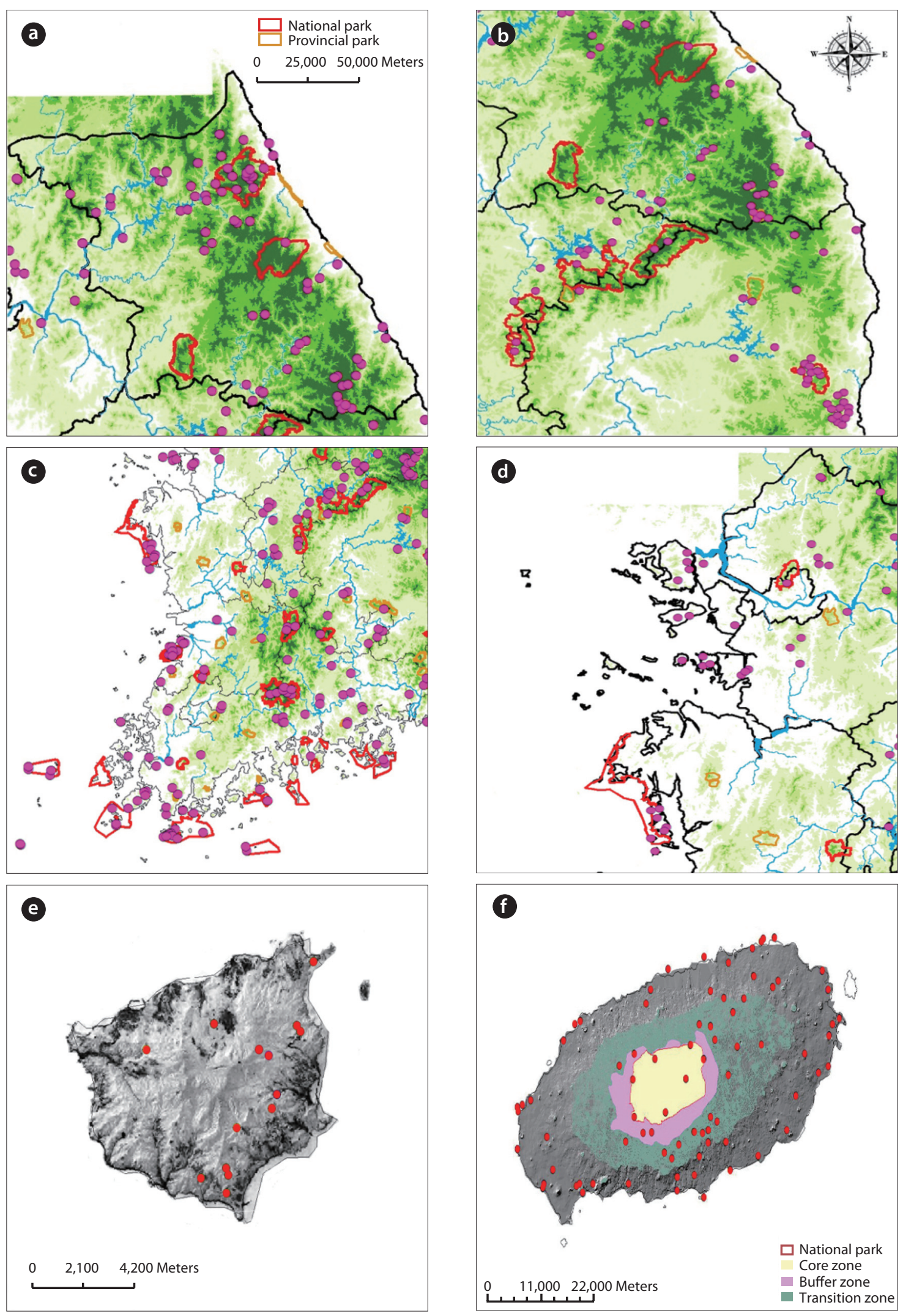

Fig. 5. Regions where a large portion of endangered species are found in habitats outside protected conservation areas in Korea. (a) Gangwon Province. (b) Gap area between Oedaesan National Park and Juwangsan National Park. (c) Coastal areas in the southwest of Korea. (d) Ganghwa Island. (e) Ulleung Island. (f) Jeju Island. 
Youngheung islands (Fig. 5d). On Ulleung Island, which has never been connected to land, endemic species such as Bupleurum latissimum, Cotoneaster wilsonii, Scrophularia takesimensis, and Vexillabium yakushimense var. nakaianum were detected. In particular, Cotoneaster wilsonii generally resided along the coast (Fig. 5e).

On Jeju Island, there were a total of 22 endangered species making the island their habitat. They included the following: six class I species (Aerides japonicum, Cymbidium kanran, C. lancifolium, Diapensia lapponica var. obovata, Euchresta japonica, and Neofinetia falcata), and 16 class II species (Asplenium antiquum, Cymbidium macrorrhizum, Galeola septentrionalis, Hibiscus hamabo, Isoetes japonica, Lasianthus japonicas, Mankyua chejuense, Osmanthus insularis, Paeonia obovata, Paliurus ramosissimus, Psilotum nudum, Quercus gilva, Sarcandra glabra, Sarcanthus scolopendrifolius, Saururus chinensis, and Utricularia yakusimensis) (Fig. 5f). However, only four species (Diapensia lapponica var. obovata, Galeola septentrionalis, Isoetes japonica, and Utricularia yakusimensis) were found inside the Hallasan National Park. The rest of the endangered species were distributed across various sightseeing facilities and road sites on the island.

\section{DISCUSSION}

Although the distribution of endangered or threatened species has been examined sporadically (e.g., Hyun 2002), this study is the first to report on the potential causes responsible for the endangerment of plant species in Korea. Excluding the small population category, endangered plant species in Korea are more frequently associated with extrinsic factors than with intrinsic factors. This result is consistent with a number of previous studies in which the influence of cropland expansion and urbanization on species endangerment and extinction was emphasized (e.g., Vitousek et al. 1997, Wilcove et al. 1998, Czech et al. 2000, Department of Sustainability, Environment, Water, Population and Communities, Australian Government 2005). On the other hand, the endangerment of species appears to be related weakly to unique ecological characteristics. However, considering the fact that the biology of endangered and native species is currently not well known, the small effects of ecological characteristics are more likely a result of a lack of information than any absence of effects of ecological characteristics. As species differ in their response to environmental changes, endangered species conservation can only be appropriately achieved when we understand the types of past threats to those species.

Recently, Noss et al. (2009) reported that $28.6 \%$ of the vascular plant species in United States are critically imperiled, imperiled, or vulnerable species, collectively referred to as "threatened species." According to the most recent report of the IUCN (2010a), among 7,000 plant species examined, $22 \%$ are under threat, and $33 \%$ could not be evaluated due to a lack of information. By way of contrast, less than $2 \%$ of about 4,000 vascular plant species in Korea are designated as endangered species. Such a large difference in the proportion of endangered species is not likely to reflect an actual difference in endangerment, but rather a difference in information sufficiency and endangerment criteria.

Several authors have argued against the definition and categorization of endangered species (e.g. Kim 1994, Bang and Ahn 2005, Chang et al. 2005). For example, when determining the level of endangerment of those 64 species according to the IUCN's Red List, 33 are categorized as species of least concern, which have only a slim chance of extinction (Kim et al. 2001, Chang et al. 2005). Additionally, current lists of endangered species may not represent Korean plant species' phylogenetic or evolutionary diversity. For example, certain groups of plants such as the Orchidaceae, Ranunculaceae, and Liliaceae appear to be overrepresented. On the other hand, gymnosperms and endemic species are underrepresented. Gymnosperms are in more danger of extinction than birds or mammals (IUCN 2010a). Approximately 70 gymnosperm species are present in Korea (Korea Forest Service 2010), and four of them--e.g., Abies koreana, Larix olgensis for. viridis, Taxus cuspidata var. nana, and Blatycarya strobilacea var. coreana--are endemic species. However, not a single gymnosperm species is listed as endangered. Endemic species are also scant among endangered species, accounting for only 2.7\% (14 species, including Iris koreana, Mankyua chejuense, and Scrophularia takesimensis), among 515 endemic species (73 families). Therefore, endangered species, which are concentrated toward particular lineages, appear to indicate that the listing of endangered species was made with greater emphasis placed on the ornamental or economic value of species, rather than on the actual degree of family or species endangerment.

Most species in danger of extinction may consist of one or just a few populations, and their populations tend to be rather small in size. Therefore, population dynamics information is critical to evaluations of endangerment. Reproductive ecology is a key component 
affecting population parameters (Kang and Bawa 2003), but studies concerning the reproductive ecology of endangered species in Korea are relatively limited (Yu et al. 1976, Kang et al. 2000, So et al. 2008). Almost all endangered species, excluding a few such as Isoetes japonica, Mankyua chejuense, and Psilotum nudum, undergo outcrossing facilitated by attractive flowers, fragrance, and/ or nectar. For example, orchids, which comprise a large percentage $(15 \%)$ of endangered species, are typical outcrossing plants, and engage in unique symbiotic relationships with mycorrhizae. Additionally, many endangered species, such as Cotoneaster wilsonii, Jeffersonia dubia, and Osmanthus insularis, require animal vectors for their fruit or seed dispersal. Therefore, in-depth studies into the population biology of endangered species are clearly required, and endangered species research should be extended beyond a single species to encompass the relationships among species, as previously suggested by Wilson et al. (2007).

The IUCN (1993) urges that $10 \%$ of land in each country be set aside as conservation areas, because habitat loss and degradation are the principal factors responsible for the extinction of species of diverse taxa. However, excluding sea area, Korean conservation areas comprise only $4.9 \%$ of the land, and must be doubled to meet the IUCN's $10 \%$ coverage target. Doubling the size of conservation areas is not easy: the acquisition of new land, particularly larger parcels, frequently involves great costs, both economically and socially. Then, for the limited conservation areas, methods to support the ecosystem functions, including high biodiversity, must be devised.

In this study, we determined that the number of endangered plant species increases in a linear fashion with the size of the national park. Only two endangered plant species are observed in the secondary conservation areas, i.e., provincial parks, ecosystem conservation areas, and wetland conservation areas, all of which are far smaller in area than the national parks. This may reflect the effect of small size. Similar area effects have also been reported for vascular plants, as well as introduced plants, butterflies, and birds in Korean western and southern sea islands (Choi 2000, Chung and Hong 2002, Rho 2010). Several small reserves may be particularly inappropriate for areas characterized by high biodiversity, highly endemic taxa, or certain taxa such as vertebrates (e.g., Rodrigues and Gaston 2001). However, several authors have argued that several small reserves, if selected carefully, can prove quite successful in meeting conservation needs (Primack 1993, Turner and Corlett 1996).

The Global Strategy for Plant Conservation (United
Nations Environment Programme 2010) proposed a target for plant conservation, i.e., in situ conservation of at least $60 \%$ of threatened species. A total of $69 \%$ of species are observed in national parks. On one hand, it appears that the Korean conservation areas fulfill the objective of $60 \%$ species coverage. This result indicates that conservation networks may have to be centered on existing national parks from Seorak in the north to Hallasan National Parks in the southernmost part of Korea. On the other hand, $31 \%$ of endangered species are found outside the protected areas. Considering that only $5 \%$ of the land is protected as a conservation area, it is unsurprising that fully one-third of endangered species inhabit unprotected areas.

As suggested previously by Possingham et al. (2005), locating gap areas in which the density of endangered or key species is high but is not protected by law, and adding it as a new conservation area or conservation network component may prove a more feasible conservation option. The Global Strategy for Plant Conservation (United Nations Environment Programme 2010) suggests protecting $50 \%$ of the most important areas for plant diversity. Although we did not, in this study, quantify the percentage of gap areas in which endangered species are concentrated but not protected by law, Figs. 2 and 3 clearly demonstrate that the conservation areas do not fulfill the Global Strategy's 50\% land coverage goal. By way of contrast, five species (Acanthopanax senticosus, Iris koreana, Lilium cernuum, Paeonia obovata, and Trientalis europaea var. arctica) reside in more than six national parks. Endangered species are, basically, rare species. According to the study of Vellak et al. (2009) conducted in Estonia, naturally rare species which reside in unique habitats or perpetually maintain small populations need conservation areas twice the size of those of anthropogenically rare species. If this is indeed the case, different management methods must be devised depending on different endangered species' distributions and sensitivity of those species to human activities.

In Fig. 5, the region between Odaesan National Park and Juwangsan National Park, mountain regions of Gangwon Province and Gyeongsangbuk Province, southwestern coast, and islands such as Gangwha, Jeju, and Ulleung appear to be important gaps in the conservation of endangered species. In order to maintain the endangered species in these areas, we must understand the areas' historic landscapes and native vegetation. For example, Jeju and Ulleung's particular landscape and vegetation are important resources in and of themselves, and these two islands, at a national level, are focal sites in species 
diversity. One-third of Korea's endangered species reside on Jeju Island, but the majority of them inhabit the shore and/or lowland, which are not legally protected areas. Habitats in Jeju are undergoing fragmentation through road construction and tourist facility increases, resulting in the isolation and/or destruction of wild species habitats (Kang et al. 2008). Due to road construction, endemic species such as Bupleurum latissimum and Scrophularia takesimensis on Ulleung Island are also exposed to habitat loss and degradation (Hyun 2002). Therefore, although protected lands have, thus far, been established primarily in mountainous areas, conservation efforts in Jeju Island and Ulleung Island must focus on the coast and lowland, where anthropogenic activities are relatively widespread.

In the face of rapid environmental changes such as human population increases, urbanization, and climate changes, converting the gap areas to endangered species' habitats, or at least including them in the habitat networks, would help to enable the continued existence of endangered species. This should be quite possible because new conservation areas have continued to increase in Korea. Similar analyses can be conducted for endangered or key species of other taxa, such as birds or vertebrates. Upon the expansion or connection of conservation areas, gaps in common among key taxa should be afforded priority as new conservation areas.

\section{LITERATURE CITED}

Bang SW, Ahn S. 2005. Development of Red List Categories and Criteria for the Protection of Endangered Species in Korea. Korea Environment Institute, Seoul, pp 332. (in Korean)

Chang CS, Seok HD. 1997. Prediction of forest land decrease and preservation planning: a case of the surrounding areas of Seoul. J For Econ Res 5: 1-12. (in Korean)

Chang CS, Lee HS, Park TY, Kim H. 2005. Reconsideration of rare and endangered plant species in Korea based on the IUCN Red List categories. Korean J Ecol 28: 305-320. (in Korean)

Choi SW. 2000. Study on the ecological influences on the butterfly fauna of islands in Korea: roles of island area, isolation, latitude and maximum elevation. Korean J Environ Biol 18: 237-246.

Chung JM, Hong KN. 2002. Relationships between geographical conditions and distribution pattern of plant species on uninhabited islands in Korea. Korean J Ecol 25: 341-348.

Czech B, Krausman PR, Devers PK. 2000. Economic asso- ciations among causes of species endangerment in the United States. BioScience 50: 593-601.

Department of Sustainability, Environment, Water, Population and Communities, Australian Government. 2005. Threatened species and ecological communities. http://www.deh.gov.au/biodiversity/threatened/index. html. Accessed 4 October 2010.

Environmental Systems Research Institute. 2004. Arc/Info User's Guide. Ver. 9.0. Environmental Systems Research Institute, Redlands, CA.

Green Korea United. 2008. Baekdudaegan is cut off by the roads every $8.3 \mathrm{~km}$. http://www.greenkorea.org/zb/ view.php?id=activity_news $01 \&$ no=75. Accessed 5 October 2010. (in Korean)

Groom MJ. 2005. Threats to biodiversity. In: Principles of Conservation Biology (Groom MJ, Meffe GK, Carroll CR, eds). Sinauer Associates, Sunderland, MA, pp 63-109.

Hyun JO. 2002. Categorization of the threatened plant species in Korea. PhD Dissertation. Soonchunhyang University, Asan, Korea. (in Korean)

IUCN. 1993. Parks for Life: Report of the $4^{\text {th }}$ World Conference on Natural Parks and Protected Areas. IUCN, Gland.

IUCN. 2010a. News release: new study shows over one fifth of the world's plants are under threat of extinction. http:// www.iucnredlist.org/news/srli-plants-press-release. Accessed 3 October 2010.

IUCN. 2010b. The IUCN Red List of threatened species: classification schemes. http://www.iucnredlist.org/technical-documents/classification-schemes. Accessed 3 October 2010.

Kang H, Bawa KS. 2003. Effects of successional status, habit, sexual systems, and pollinators of flowering patterns in tropical rain forest trees. Am J Bot 90: 865-876.

Kang H, Kim H, Chang E. 2008. Landscape analysis of the Hallasan National Park in a Jeju Island biosphere reserve: Fragmentation pattern. Korean J Environ Ecol 22: 309-319. (in Korean)

Kang U, Chang CS, Kim YS. 2000. Genetic structure and conservation considerations of rare endemic Abeliophyllum distichum Nakai (Oleaceae) in Korea. J Plant Res 113: 127-138.

Kim YS. 1994. The necessity of evaluation criteria selections for Korean rare and endangered plant species. Korean J Environ Ecol 8: 1-10. (in Korean)

Kim YS, Chang CS, Kim H. 2001. Reconsideration of rare and endangered plant species in Korea based on the IUCN Red List categories. Korean J Plant Taxon 31: 107-142. (in Korean)

Korea Forest Service. 2010. Korean Plant Names Index. 
http://www.nature.go.kr/kpni/. Accessed 3 October 2010. (in Korean)

Mawdsley JR, O'Malley R, Ojima DS. 2009. A review of climate-change adaptation strategies for wildlife management and biodiversity conservation. Conserv Biol 23: 1080-1089.

Ministry of Environment. 2003. White Paper on the Environment. Ministry of Environment of Korea, Gwacheon. (in Korean)

Ministry of Environment. 2005a. Endemic Species of Korea. Ministry of Environment of Korea, Gwacheon. (in Korean)

Ministry of Environment. 2005b. Satellite images. http:// egis.me.go.kr/egis/. Accessed 3 October 2010.

Ministry of Environment. 2005c. Wild fauna and flora of Korea: the biotic resources distribution map. http://nre. me.go.kr/meweb/w03/w0304s01.jsp. Accessed 5 October 2010. (in Korean)

Ministry of Environment. 2006. White Paper on the Environment. Ministry of Environment of Korea, Gwacheon. (in Korean)

Ministry of Environment. 2007. White Paper on the Environment. Ministry of Environment of Korea, Gwacheon. (in Korean)

Ministry of Environment. 2008. White Paper on the Environment. Ministry of Environment of Korea, Gwacheon. (in Korean)

National Geographic Information Institute. 2003. http:// www.ngii.go.kr/geography/map_main.do?mainMenu=3 \&subMenul=1\&subMenu2=1. Accessed 9 October 2010.

National Parks of Korea. 2009. Endangered species. http:// english.knps.or.kr/Archive/Endanger/Default.aspx?Me nuNum $=4 \&$ Submenu=Endangeredspecies. Accessed 3 October 2010.

Noss RF, Fleishman E, Dellasala DA, Fitzgerald JM, Gross MR, Main MB, Nagle F, O'Malley SL, Rosales J. 2009. Priorities for improving the scientific foundation of conservation policy in North America. Conserv Biol 23: 825-833.

Possingham HP, Wilson KA, Andelman SJ, Vynne CH. 2005. Protected areas: goals, limitations, and design. In: Prin- ciples of Conservation Biology (Groom MJ, Meffe GK, Carroll CR, eds). Sinauer Associates, Sunderland, MA, pp 509-551.

Primack RB. 1993. Essentials of Conservation Biology. Sinauer Associates, Sunderland, MA, pp 564.

Rho P. 2010. Species richness related to landscape characteristics of uninhabited islands in Korea. J Ecol Field Biol 33: 105-114.

Rodrigues ASL, Gaston KJ. 2001. How large do reserve networks need to be? Ecol Lett 4: 602-609.

So S, Han K, Kim M, Park H, Seo Y, Kim YP, Kim TH. 2008. Pollination mechanism of Bupleurum latissimum (Apiaceae). Korean J Plant Taxon 38: 43-50. (in Korean)

Turner IM, Corlett RT. 1996. The conservation value of small, isolated fragments of lowland tropical rain forest. Trends Ecol Evol 11: 330-333.

United Nations Environment Programme. 2010. Convention on biological diversity: the global strategy for plant conservation. http://www.cbd.int/decision/cop/?id=7183. Accessed 6 October 2010.

Vellak A, Tuvi EL, Reier Ü, Kalamees R, Roosaluste E, Zobel M, Pärtel M. 2009. Past and present effectiveness of protected areas for conservation of naturally and anthropogenically rare plant species. Conserv Biol 23: 750-757.

Vitousek PM, Mooney HA, Lubchenco J, Melillo JM. 1997. Human domination of Earth's ecosystems. Science 277: 494-499.

Wilcove DS, Rothstein D, Dubow J, Phillips A, Losos E. 1998. Quantifying threats to imperiled species in the United States. BioScience 48: 607-615.

Wilson KA, Underwood EC, Morrison SA, Klausmeyer KR, Murdoch WW, Reyers B, Wardell-Johnson G, Marquet PA, Rundel PW, McBride MF, Pressey RL, Bode M, Hoekstra JM, Andelman S, Looker M, Rondinini C, Kareiva P, Shaw MR, Possingham HP. 2007. Conserving biodiversity efficiently: what to do, where, and when? PLoS Biol 5: e223.

Yu TY, Yeam DY, Kim YJ, Kim SJ. 1976. Studies on dimorphism and heterostyly-incompatability of Abeliophyllum distichum. Seoul Nat Univ J Agric Sci 1: 113-120. (in Korean) 